УДК [94 : $061.2: 17.035 .3: 351.858]$ (477.82) «1921-1939»

DOI: https://doi.org/10.33782/eminak2021.2(34).522

\title{
SOCIO-POLITICAL AND PUBLIC ORGANIZATIONS ACTIVITY PECULIARITIES AT VOLYN IN THE UKRAINIAN STATEHOOD IDEA FORMATION AND DEVELOPMENT IN 1921-1939
}

\author{
Oleksandr Kadeniuk1, Vasyl Sazhko² \\ 1 Podilsk State University (Kamianets-Podilskyi, Ukraine) \\ e-mail: akadenyuk@gmail.com; ORCID: https://orcid.org/0000-0002-2173-6055 \\ 2 National University «Yuri Kondratyuk Poltava Polytechnic» (Poltava, Ukraine) \\ e-mail: sazhkovv@gmail.com; ORCID: https://orcid.org/0000-0002-4372-3570
}

Historical aspects of the development and formation of socio-political and public organizations in Volyn, which after the end of the World War I was under the rule of two totalitarian powers - the Soviet Union and the Polish-Lithuanian Commonwealth I is studied in the article. The role of Ukrainian immigration in the creation of Ukrainian socio-cultural and political centers was considered, and the optimal ways of solving national problems were searched for. On the example of Volyn lands it is proved that despite the difference of social and political systems, which dominated both Western and Eastern parts of Volyn, the process of formation of the national idea represents an organic unity in all Ukrainian lands.

Keywords: Ukraine, Volyn, national movement, public organizations, socio-political organizations

The level of national consciousness and national-organizational life in Volyn in the period preceding World War I was characterized by a special rise. This was influenced by historical factors. As is known, the Galicians lived under the rule of the constitutional Austro-Hungarian Empire and had some experience of political and economic selforganization. Ukrainians, who lived within absolutist tsarist Russia, had no such experience. Prior to World War I, the national movement in Volyn, Polissia, Kholmshchyna and Pidliashshia had not acquired any organizational forms. By the level of socio-political activity and national consciousness of the population of the region stood far below the Galicians. It was only during the Ukrainian Revolution and the first post-war years, when many political activists and representatives of Ukrainian intelligentsia from the Dnieper region emigrated to Volyn, that the national movement was revived to a certain extent. Political disenfranchisement, social and national oppression determined the growth of revolutionary and national liberation movements among various strata of the population in the Volyn lands.

The study is based on the analysis of scientific works and archival sources on ethnonational relations, the national policy of the governments of Poland and the Soviet Union on the ethnic population of Volyn in the interwar period. In modern historical science, this problem is given enough attention in the works of M. Kucherepa, K. Fotyev, V. Rozhko, O. Kadeniuk, O. Solovei, I. Zavadska, R. Davydiuk, S. Kacharab, J. Tsetsyk and others ${ }^{1}$.

\footnotetext{
1 Давидюк Р. Розмежування Західної Волині та Східної Галичини як складова «волинського експерименту» Генрика Юзевського // Сучасна українська держава: історичні імперативи станов-
} 
However, national-cultural processes and ethno-national peculiarities of the region, based on which there was a political and religious component, require further research.

The purpose of this study is to determine the place and role of socio-political and public organizations of Volyn in the 1920s-30s in the dissemination of the ideas of Ukrainian statehood and the formation of ethno-national relations in Volyn, under the rule of totalitarian regimes.

One of the reasons that Volyn lands became an environment in which national movement in the interwar period actively developed was and on Volyn and Polissia, after the defeat of the revolution, settled the military armies of the UPR. These people were united with the local population of the same Orthodox faith. In Catholic Galicia the cooperation of Orthodox immigrants from the banks of the Dnieper with the local population was not so favorable ground.

Former UPR soldiers in immigration constantly considered themselves faithful to the oath given to the legitimate government of the Ukrainian People's Republic and carried this idea to the broad masses of the people. Considering that there was a conscious patriotic element in the ranks of the Ukrainian army during the liberation struggle, and when the army retreated from Ukraine, these people stayed by the thousands by order of the Chief Ataman for the partisan struggle, their influence on the growth of national consciousness in Volyn was decisive.

In contrast to the party infighting that broke out between Ukrainian political parties during the interwar period, most of those who fought in Symon Petliura's army promoted the idea of the consolidation of all the creative forces of the entire nation on the basis of the republican concept of the UPR as the legitimate state center of Ukraine. They hardened and educated young people in their spirit of the national struggle. Their cult of the People's Republic turned under the occupation of Ukrainian lands into a new political and military ideology, which rather quickly seized the sentiments of the local population.

Former generals, colonels, centurions, platoon and private soldiers, and former ministers, directors of departments and various civil servants, having lost their state, went into the popular masses. They became bishops, priests, private teachers, editors, farmers, loggers, merchants, etc., while continuing to do great educational and revolutionary work. They were fanatics of the national idea, their loyalty and unity showed in the years of struggle for the Ukrainian state on many fronts, and after the war further served the same idea as the advanced elite of the nation ${ }^{2}$.

In the 20s and 30s of the twentieth century there was an intensive development of the ideology of Ukrainian nationalism. The leading role here was played by the figure of Dmy-

лення, тенденції та проблеми розвитку: збірник / редкол.: Ю.А. Левенець [та ін.]. Київ, 2006. С. 498-509; Цецик Я.П. Діяльність українських національних партій на Волині у міжвоєнний період: автореф. дис... к. іст. н. Чернівці, 2008. 20 с.; Качараба С.П. Еміграція з Західної України: (19191939). Львів: [Місіонер], 2003. 416 с.; Кучерук О., Червак Б., Матеріали до історії ОУН. Київ: Вид-во ім. Олени Теліги, 1997. 39 с.; Кучерепа М. Національна політика Другої Речі Посполитої щодо українців (1919-1929 рр.) // Україна - Польща: важкі питання. Матеріали II міжнародного семінару істориків «Українсько-польські відносини в 1918-1947 рр.». Варшава, 12-24 травня 1997 р. Варшава, 1997. С. 11-28; Соловей О.Г. Імміграційні процеси на Волині у міжвоєнний період (19211939 рр.): Автореф. дис... к. іст. н. Львів, 2004. 22 с.; Каденюк О.С. Громадсько-просвітницькі організації Волині у 20-х - 30-х роках XX століття // Вісник Східноукраїнського університету ім. Володимира Даля: Наук. журн. Сєвєродонецьк, 2020. Вип. 3. С. 32-36; Zavadskaya, I., \& Kadenyuk, A. Political Factors in the Formation and Activity of Agricultural Societies in East Galicia (20s early 30s XX century) // Zaporizhzhia Historical Review. 2019. № 1 (52). P. 150-154.

2 Бульба-Боровець Т. Армія без держави. Львів: Поклик сумління, 1993. 166 с. 
tro Dontsov. His concept among a significant part of the Volyn population, especially among young people, awakened the national spirit, instilled optimism, and educated a new generation of fighters. It was not devoid of logic, because at a time of general decline, the ignoring of the Ukrainian problem by the wide world community, gave a sense of uplift and faith in the Ukrainian national idea 3 .

Not only Dontsov's theories and ideas penetrated Volyn and had an impact on raising the national consciousness of the population, but also his frequent visits to Kovel and other cities and meetings with well-known Ukrainian public and political figures who were in immigration. In particular, family and ideological ties with the ambassador to the Polish Sejm from Volyn by Samiilo Pidhirskyi ${ }^{4}$. As a consequence, next to the old Dnieper intelligentsia in immigration, a new generation was born - young people who were oriented to the idea of independence of Ukraine. After the creation of the OUN, national ideas spread especially quickly among students. Despite the fact that the OUN leadership was abroad and the Provincial Execution, was functioning in the region, the beginning of the 1930s was characterized by a number of terrorist actions against the Polish administration. This struggle seized wide circles of first students and middle-schoolers, and then of workers and peasants.

After the repressions of 1930-1931, carried out by the Polish government, the OUN cells were destroyed. In this connection, at a meeting of the OUN leaders in 1932 at the Congress in Prague, it was declared necessary to continue the work in Volyn 5 .

The main burden of organizational and ideological work was taken on by the student gymnasium youth. Teachers and mentors in the new conditions were the same Ukrainian figures in immigration. As Oleh Shtul, a graduate of the Kremenets Orthodox Ukrainian Seminary, recalled, Ukrainian nationalism was taught to the youth by the political envoy (immigrant) Roman Bozheskyi6. The young people received an ideological training, learning to think in what ways to gain the independence of Ukraine. The number of OUN members, especially among the youth, grew rapidly. If in 1932 the police registered 16 manifestations of the UUN activity in Volyn, then in 1933 there were already 100 of them. In the autumn of 1933, there was a trial of gymnasium students and students in Volyn, who were accused of reading and distributing nationalist literature. Twenty boys and 11 girls were convicted 7 .

The names of students who were affiliated with nationalist organizations are often mentioned in Polish police summaries, especially the distribution of illegal literature, the display of national flags, the celebration of national holidays, speeches against the authorities, etc. After a census of students in 1934, it became known that over $50 \%$ of Volyn students were members or sympathizers of the UUN and UNDP8.

\footnotetext{
3 Червак Б. Нації військо незриме // Матеріали до історії ОУН. Київ: Вид-во ім. Олени Теліги, 1997. C. 3-16.

4 Рожко В. І потекла сторіками... Могили не можуть мовчати. Вінніпег, Канада: Спадщина, 1994. C. $246-252$.

5 Савчук О., Савчук I. Волинське студентство 1920-30-х років - нова генерація української національної інтелігенції I половини XX ст. // Тези доповідей та повідомлень Міжнародної наукової конференції «Волинь і волинське зарубіжжя», Луцьк 16-18 червня 1994 р. Луцьк, 1994. С. 8385.

6 Зварник Г. Загадковий «вістківець» Роман Божеський. Листи до Дмитра Донцова // Українські проблеми. 1997. № 2. С. 145-146.

7 Державний архів Волинської області (ДАВО). Ф. 1. Оп. 2. Спр. 416.

8 Ibidem.
} 
Political powerlessness, brutal social and national oppression conditioned the growth of the national liberation movement in the Volyn lands. Nationalist ideology was increasingly penetrating the Volyn environment.

Despite persecution and repression by the Polish authorities, Volyn was increasingly drawn into the national struggle for independence. Volyn Voivode Henryk Yuzevskyi, searching for compromise with the Ukrainian, simultaneously waged an uncompromising struggle against Ukrainian nationalism. Since, according to the voivode, nationalism, as well as communism, were brought to Volyn from neighboring Galicia, between Volyn and Galicia was strengthened, the so-called «Sokal border», through which it was forbidden to transport the Ukrainian press and literature 9.

However, neither repression nor the borders could stop the growing national liberation movement. Evidence shows that this movement was supported and often organized by immigrants. Indicative in this regard is the figure of the Ukrainian public and political figure, journalist, and editor Hryts Hladkyi. A native of Galicia, he fought at the front during the war and was later taken prisoner by Russia. He was stationed in Siberia and the Urals. With the beginning of the revolution of 1917. He returned to Ukraine, served in the formations of Sich Riflemen, the army of the Ukrainian People's Republic with the rank of centurion and occupied the post of chief of cultural and educational department of the Ukrainian 6th Infantry Division. He continued his cultural and educational activities after the war in the camp of interned UNR soldiers in Kapisht (Poland).

Hladkyi's active political and social activities began in immigration to Volyn in 1922. On the occasion of the first elections to the Polish Sejm in 1922 he went to Lutsk, where as one of the closest employees of Ambassador S. Pidhirskyi, and later as a secretary of the Polish secretariat of the Ukrainian parliamentary representation in Volyn, he devoted himself to intensive national and social organizational work. Being an active educator, he took part in the development of «Enlightenment» in Volyn, and was involved in the foundation of the Ukrainian Cooperative Bank in Lutsk. In 1925 Hladkyi was one of the founders of the Ukrainian newspaper «Ukrainska Hromada», which was coming out in Lutsk in 1926-1929. His articles-commentaries about the Ukrainian political and social life in Volyn were of great relevance and importance.

In $1928 \mathrm{H}$. Hladkyi became an active member of the Ukrainian National Democratic Association. In the same year, after six years of political and public work in Volyn, he moved to Lviv, where he combined socio-political, public, journalistic and editorial activities. While in Galicia, he maintained close ties with influential socio-political figures of Volyn, with whom he cooperated for a long time.

From ideological publications of H. Hladkyi attract attention those in which the preservation of the identity of the Ukrainian people, the achievement of the centuries-old dream of Ukrainian - Ukrainian statehood is in the foreground. In particular, it is a theoretical article about the historical events of the end of January 1918 and 1919 «Memorable days» ${ }^{10}$.

The Ukrainian population of Volyn during the period of its separation in the 1920s30s was subjected to strong ideological influence of the Polish and Soviet regimes aimed

\footnotetext{
9 Кучерепа М. Національна політика Другої Речі Посполитої щодо українців (1919-1929рр.) // Україна - Польща: важкі питання. Матеріали II міжнародного семінару істориків «Українськопольські відносини в 1918-1947 рр.». Варшава, 12-24 травня 1997 р. Варшава, 1997. С. 11-28.

10 Галушко М. Гладкий Гриць // Українська журналістика в іменах. Матеріали до енциклопедичного словника. Вип. 6. Львів, 1999. С. 61-64.
} 
at the destruction of national consciousness. The governments of the two countries in the sphere of political influence of which there were Volyn lands, developed special measures aimed at assimilation of the Ukrainian people. The theory of the rapprochement of nations, their fusion into a new historical community of people - the Soviet people, was a hidden goal in the national policy of russification of ethnic Ukrainians. The Polish political leadership also pursued a similar policy of Polonization and turning to Catholicism. Thus, the population of Volyn in the interwar twentieth century was subjected to forced ethnic assimilation. However, the Ukrainian language and Ukrainian ethnos were much more stable than the theorists of fusion of nations and Polonization imagined. Due to historical circumstances, the Volynians developed a strong sense of national identity, preserved their national language, the Orthodox faith, and the national church. The idea of a national church, which was realized in Volyn in the period between the two world wars, became the ethno-confessional core of the ethnic spirituality of the people, a necessary condition for the national and state rebirth of Ukraine.

In the interwar period, active figures of the national liberation movement, who were in immigration in Western Volyn, stood on the guard of national interests. They continued the struggle both in the sphere of political activity and in the sphere of cultural and national life. The instinct of self-preservation produced over the centuries under the constant threat of foreign enslavement, the way of social behavior, which is reflected in folk customs, beliefs, attitude to each other, to labor, to language, was the protective mechanism that saved Volyn from assimilation. Immigrants in the Western Volyn lands remained generators of the idea of national integrity and bearers of national memory. It was the awareness, knowledge and preservation of the language that provided reliable protection against changes in national consciousness. Historical experience confirms that when a nation has preserved its language, it is sure to restore its statehood, because these two categories are inextricably linked.

Problems of native language and culture were at the heart of the activities of the Society «Prosvita» and other cultural and educational institutions, were raised at the level of the Polish Sejm and Senate by Ukrainian ambassadors and senators, and were nurtured and popularized by individual public figures. One such Ukrainian public figure was Modest Levytskyi, a physician, writer and publicist, a member of the national liberation struggle and a member of the government of the UPR. Being an immigrant in Volyn, working in Lutsk, he successfully combined two professional duties - as a doctor and a publicist. His publications, among which the main place belonged to the problems of the native language and writing, were widely known among the general public of the Ukrainian intelligentsia. The main motives of his works were the preservation and unification of the spiritual potential of the nation, so that Ukrainian writing language was one for the whole country ${ }^{11}$. There were many such associates in Volyn. In the eastern Volyn lands it was brightly manifested in the period of national-cultural revival of the 1920s, which went down in history as Ukrainianization.

Ukrainian immigration to Volyn in the interwar period was an exponent of the ideas of national independence. In the conditions of totalitarian regimes, its brightest representatives continued their struggle by all available means. The Soviet and Polish authorities through terror and repression tried to suspend or even destroy the national-cultural

\footnotetext{
11 Сидоренко Н. Левицький Модест Петрович // Українська журналістика в іменах. Матеріали до енциклопедичного словника. Вип. 6. Львів, 1999.
} 
process of Ukrainians, to limit their political rights and freedoms. In the fates of immigrants is reflected the tragedy of the era. They lived in a complex and tumultuous historical time, which absorbed the heroism and drama of the revolutionary upheaval era. It was a time of creating their own state and fighting for it. A considerable part of Ukrainian immigrants in Volyn were participants and creators of the new history of Ukraine, they felt the greatness of the ups and the shame of the fall, victory and bitterness of defeat. The consequence of political activity for many of them was the status of an immigrant in their Ukrainian Volyn land, but already under the rule of other political regimes. Immigrants have always felt the scrutiny of the security services. And very often the very fact of immigration and political past became a sentence for many of them, especially in Soviet Ukraine. Already at the end of the 1920s the rebel ataman, organizer and leader of the Second Winter campaign of the UPR army - Yurii Tiutiunnyk was secretly executed in Butyr prison in Moscow. After Tiutiunnyk crossed the Soviet border the SPD organs used him for some time for propaganda of communist ideas and for creation of an intelligence network in favor of the USSR. Remorse for his participation in the struggle for Ukrainian statehood, described in his memoirs «With Poles against Ukraine» and widely disseminated by the Soviet authorities ${ }^{12}$, and his participation in the activities of the espionage and sabotage committee «Center» set up by the Soviet secret services did not save the life of Y. Tiutiunnyk who was liquidated by the SPD authorities ${ }^{13}$.

In the middle of the 1930's many members of the CPWU and those who for political reasons emigrated from West Volyn to Soviet Ukraine became victims of mass terror in the USSR. Among them were the well-known worker of the CPWU Olha Platonova14, the publicist and political activist Marko Lutskevych ${ }^{15}$, and a pupil of the Kremenets Gymnasium Andrii Zhdanovych, who wanted to study in the USSR, but was arrested by the NKVD as an enemy of the people and was shot. In exile in the Far East served his sentence as a poet, an active participant in the creation in Zhytomyr communities of the Ukrainian Autocephalous Orthodox Church, Mykola Khomychevskyi, literary pseudonym of Borys Ten ${ }^{16}$.

Active socio-political figures in immigration in Western Volyn felt the double blows of totalitarian regimes and established domination of Ukrainian lands. Many immigrants found themselves in Western Volyn because of the retreat of the UPR army and therefore, in the face of hostilities, were unable to transport their families to immigrate. In 1929, the wife of Vasyl Bidnov, a well-known professor and church historian at the time, was arrested. Liubov Bidnova, who worked as a teacher in Dnipropetrovsk, together with a professor of the Dnipropetrovsk Institute of Public Education Petro Yefremov and a student Mykola Bilyi, was accused in the ULU case, for which she was convicted and died in exile.

\footnotetext{
12 Тютюнник Ю. 3 поляками проти Вкраїни: Репринтне відтворення видання 1924 року. Київ: Україна, 1990.103 с.

13 Савчук О., Комар В. Волинські шляхи генералів УНР: Володимир Оскілко та Юрій Тютюнник // Матеріали регіональної наукової краєзнавчої конференції «Південно-Східна Волинь: наука, освіта, культура». Хмельницький - Шепетівка, 1995. С. 164-165.

14 Чернихівський Г. Кременеччина від давнини до сучасності. Кременець: Папірус, 1999. 320 с.

${ }^{15}$ Степанов Л., Степанова Л. Народний оборонець // Тези доповідей та повідомлень V Волинської історико-краєзнавчої конференції 11-13 жовтня 1991 р. «Минуле і сучасне Волині. Історичні постаті краю». Луцьк, 1991. С. 133-134.

16 Мороз В. Людина українського відродження // Кожному мила своя сторона. Краєзнавчі нариси про видатних людей, минуле Житомирщини, обряди і звичаї населення краю. Житомир: Журфонд, 1997. С. 30-33.
} 
The same tragedy happened to the family of the insurgent ataman, member of the Central Council, colonel of the army of the UPR, teacher, cooperator and banker Volodymyr Machushenko in immigration. The Bolsheviks promised a reward of 10,000 gold rubles for Machushenko's head and shot his wife Iryna. The children were smuggled to Poland. Machushenko died in immigration in Rivne in 193717.

Was killed by unknown in Gorodok near Rivne in June 1926 by UPR general in immigration V. Oskilko18. Harassment and persecution by the Polish authorities led to the premature death at age 51 of General Chorunzhev of the army of the UPR, immigrant Almazov Oleksa ${ }^{19}$.

The beginning of World War II and the entry of Soviet troops on September 17, 1939 into the territory of Western Ukraine and its annexation to the Ukrainian USSR made it impossible for the majority of active national liberation movement figures in immigration to continue to stay on the territory of Western Volyn. Understanding the inevitability of reprisals by the new authorities for political activity during the years of the Ukrainian National-Democratic Revolution and during the interwar period, a significant part of Ukrainian immigration was forced to leave Volyn and seek asylum in immigration in European countries. This period was filled with particular drama for the fate of immigrants. A new world war was breaking out in Europe on an increasing scale, so it was difficult to find political asylum under these conditions. The Soviet regime after September 1939 began the Sovietization of the annexed territories. One of the areas of this process was the fight against political opponents. Since a large number of immigrants did not leave the national-political activities in the interwar years, they were the first victims of repression. In the autumn of 1939, the former organizer of the insurgent movement in Podillia, the guerrilla ataman Ananii Volynets, was arrested on a denunciation. He had been in immigration in Western Volyn since $1920^{20}$.

Taras Bulba-Borovets, who worked closely with A.Volynets in the 1930s, wrote: «In the winter of 1940-1941 our ranks suffered a very painful loss. In Vinnitsa at the court show Bolsheviks with great pomp condemned to «capital punishment», i.e. to execution, the former rebel ataman of the Haisyn district in 1918-1920 - Colonel Volynets. He was a military expert of great magnitude, organizer of insurgent associations and mobilizer of the supply of insurgent troops. The trial, held in Vinnitsa on August 2, 1941, sentenced A. Volynets to death» 21 .

In September 1939, the provincial commissar of Podillia at the time of the Directory of the UPR, an immigrant in Volyn, a lawyer and social activist Hryhorii Stepura was arrested and exiled to Uzbekistan. In 1944 he died in exile ${ }^{22}$. The same fate awaits a public and political figure from Volyn, a senator to the Polish Senate in 1922-1928 Olena Levchanivska, who died in exile in Kazakhstan in $1943^{23}$.

A similar fate was destined for the family of a political figure, a senator of the Polish Sejm from Volyn, the publicist Mykhailo Cherkaskyi. He died in the prime of life in 1929

\footnotetext{
17 Сидоренко Н. Левицький Модест Петрович...

18 Савчук О., Комар В. Волинські шляхи генералів УНР...

19 Дмитрук В. Генерал-хорунжий армії УНР О. Алмазов і Волинь // Матеріали IX наукової історикокраєзнавчої міжнародної конференції 20-23 січня 1998 р. «Минуле і сучасне Волині: Олександр Цинкаловський і край». Луцьк: Настир'я, 1998. С. 63-64.

20 Сидоренко Н. Левицький Модест Петрович...

21 Бульба-Боровець Т. Армія без держави. Львів: Поклик сумління, 1993. 166 с.

22 Рожко В. І потекла сторіками... С. 202-205.

23 Енциклопедія українознавства / В. Кубійович, ред. Львів, 1994. Т. 4. С. 1270.
} 
from blood poisoning. At the end of 1939 his daughter Nataliia Cherkaska was arrested in Kremenets and sentenced to five years of imprisonment by the NKVD. Two months before the outbreak of war in 1941, his wife Maria Cherkaska and their granddaughter Olha were taken to Kazakhstan for settlement as dangerous criminals ${ }^{24}$.

After the German attack on the USSR, the NKVD organs began mass extermination of prisoners arrested for political reasons, who were imprisoned. The scientist and politician Serhii Bachynskyi was shot after interrogations and tortures on June 22, 1941. Arrested in February 1940 on charges that he «held the responsible position of Comrade Minister of Foreign Affairs in the counterrevolutionary government of Petliura in Ukraine, led an active struggle against the working class and revolutionary movement» and for the fact that «he continued to fight against Soviet power while in exile» 25 .

The interests of the Ukrainian lands by the new occupant, fascist Germany, brought the deployment of terror and genocide against the Ukrainian population. Volyn, which was not distinguished by the activity of national-political life in the early XX century, in the 1940s became one of the most active lands of Ukraine in the struggle for the restoration of Ukrainian statehood. Exactly on the territory of Volyn in the beginning of 1940-ies the first departments of UIA appeared, which developed into the Resistance movement, which gained the breadth of the national armed uprising.

The tragedy of Volyn was the fact that on its territory the struggle between the Soviet and German armies, the Soviet partisan detachments and the UIA broke out, as well as the struggle in the middle of the nationalist forces as a result of their split into supporters of A. Melnyk and Bandera. The victim in this struggle was the population of Volyn, which found itself in the whirlpool of this confrontation, although each of the warring parties suffered considerable losses. Former immigrants, active political and social activists were killed by the occupying German authorities, the security service of the Bandera movement or the punitive organs of the NKVD. Both the Soviet authorities and the Nazi regime in Germany were the epitome of totalitarianism, which directed its blow against the politicians of the region, seeing in them a danger to its domination of the seized lands.

Thus, the historical Ukrainian lands - Dnieper Ukraine, Galicia and Volyn in the interwar period, being in different socio-economic and political conditions, mutually influenced each other. The only Ukrainian nation, despite ideological and political obstacles, felt as one. National ideas spread throughout Ukraine. The belief in the possibility of a united, united and independent Ukrainian state lived among Ukrainians.

The national movement of the XX century, from the late 1920's to half of the 1940's became a central factor in the Ukrainian liberation struggle, is a classic example of joint action, mutual assistance and mutual complementarity between immigrants and the people on their native lands. As we know, no other Ukrainian formation of the thirties had such an influence on the development of the national struggle as the OUN. It was the immigration element in the 1930s that played a significant role in the formation and ideological and programmatic support of this organization.

On the territory of Volyn, which was part of the Ukrainian USSR, the Ukrainian na-

\footnotetext{
24 Миць М. Михайло Черкаський - політик, видавець і публіцист // Тези доповідей та повідомлень V Волинської історико-краєзнавчої конференції 11-13 жовтня 1991 р. «Минуле і сучасне Волині. Історичні постаті краю». Луцьк, 1991. С. 116-117; Чернихівський Г. Кременеччина від давнини до сучасності...

25 Літопис нескореної України. Документи і матеріали, спогади. Кн. 2. Львів: Галицька видавнича спілка, 1997. С. 120-143.
} 
tional movement could not manifest itself in its inherent organizational forms and apply the same tactics as on the lands of Western Volyn near Poland. But it manifested itself primarily in the national-cultural life in the 1920's - early 1930's. This was primarily the activity of the Ukrainian Autocephalous Orthodox Church, which by its mass publications and good organization kept a significant portion of Ukrainians in the positions of national-state and church sovereignty. The Orthodox clergy maintained close contacts with ecclesiastics of the Ukrainian Orthodox Church in immigration in Western Volyn. These facts suggest that the ideas of national independence were a phenomenon of allUkrainian meaning and significance. On the example of the Volyn lands we can trace that for all the differences in the social and political order that prevailed in both the Western and Eastern territories of Volyn, despite the different circumstances created by the dominant political regimes, the process of formation of the national idea was an organic unity in all the Ukrainian lands.

\section{REFERENCES}

Bulba-Borovets, T. (1993). Armiia bez derzhavy [Army without a State]. Lviv: Poklyk sumlinnia [in Ukrainian].

Chervak, B. (1997). Natsii viisko nezryme [The nation's army is invisible]. In Materialy do istorii OUN. Kyiv, pp. 3-16 [in Ukrainian].

Chernikhivskiy, G. (1999). Kremenechchyna vid davnini do suchasnosti [Kremenets' region from ancient times to the present]. Kremenets: Papirus [in Ukrainian].

Davydiuk, R. (2006). Rozmezhuvannia Zakhidnoi Volyni ta Skhidnoi Galychyny yak skladova «volynskoho eksperymentu» Genrika Yuzevskoho [Delimitation of Western Volhynia and Eastern Galicia as a component of the «Volyn experiment» by Henryk Yuzewski]. In Levenets, Yu.A. (Ed.). Suchasna ukrainska derzhava: istorychni imperatyvy stanovlennia, tendentsii ta problemy rozvytku, (pp. 498509). Kyiv [in Ukrainian].

Dmytruk, V. (1998). General-khorunzhyi armii UNR O. Almazov i Volyn [General-Cornet of the Army of the Ukrainian People's Republic O. Almazov and Volyn]. Proceedings of the Conference: «Mynule $i$ suchasne Volyni: Oleksandr Tsynkalovskiy i kray», (pp. 63-64). Lutsk [in Ukrainian].

Halushko, M. (1999) Hladkyi Hryts [Hladkyi Hryts]. In Ukrainska zhurnalistyka v imenakh. Materialy do entsyklopedychnoho slovnyka, (Vol. 6, pp. 61-64). Lviv [in Ukrainian].

Kacharaba, S.P. (2003). Emigratsiia z Zakhidnoi Ukrainy (1919-1939) [Emigration from Western Ukraine (1919-1939)]. Lviv: Misioner [in Ukrainian].

Kadenyuk, O.S. (2020). Hromadsko-prosvitnytski orhanizatsii Volyni u 20-kh - 30-kh rokakh XX stolittia [Public educational organizations of Volyn in the 1920s-30s]. Visnyk Skhidnoukrainskoho universytetu im. Volodymyra Dalia, 3, 32-36 [in Ukrainian].

Kubiiovych, V. (Ed.) (1994). Entsyklopediia ukrainoznavstva [Encyclopedia of Ukrainian Studies]. Vol. 4, P. 1270. Lviv [in Ukrainian].

Kucherepa, M. (1997). Natsionalna polityka Drugoi Rechi Pospolytoi shchodo ukraintsiv (19191929 rr.) [National policy of the Second Commonwealth towards Ukrainians (1919-1929)]. Proceedings of the Conference: Ukrainsko-polski vidnosyny v 1918-1947 rr. Varshava, pp. 11-28 [in Ukrainian].

Kucheruk, O. \& Chervak, B. (1997). Materialy do istorii OUN [Materials on the history of the OUN]. Kyiv [in Ukrainian].

Lialka, Ya. \& Hubka, I. (Eds.). (1997). Litopys neskorenoi Ukrainy. Dokumenty i materialy, spogady [Chronicle of unconquered Ukraine. Documents and materials, memories]. Vol. 2. Lviv: Galytska vydavnycha spilka [in Ukrainian].

Moroz, V. (1997). Liudyna ukrainskoho vidrodzhennia [The man of the Ukrainian revival]. In Kozhnomu myla svoia storona. Kraieznavchi narysy pro vydatnykh liudei, mynule Zhytomyrshchyny, obriady i zvychai naselennia kraiu. Zhytomyr: Zhurfond, P. 30-33 [in Ukrainian].

Myts, M. (1991). Mykhailo Cherkaskyi - polityk, vydavets i publitsyst [Mykhailo Cherkasky - politician, publisher and publicist]. Abstracts of Papers: VVolyn istoryko-kraieznavcha konferentsiia (1113 zhovtnia 1991 r.): "Mynule i suchasne Volyni. Istorychni postati kraiu». Lutsk, P.116-117 [in Ukrainian].

Rozhko, V. (1994). I potekla storikami... Mogyly ne mozhut movchaty [And flowed for centuries... Graves cannot be silent]. Vinnipeg, Kanada: Spadshchyna [in Ukrainian]. 
Savchuk, O. \& Komar, V. (1995). Volynski shliakhy heneraliv UNR: Volodymyr Oskilko ta Yurii Tiutiunnyk [Volyn' ways of generals of the Ukrainian People's Republic: Volodymyr Oskilko and Yurii Tiutiunnyk]. Proceedings of the Conference: «Pivdenno-Skhidna Volyn: nauka, osvita, kultura». Khmelnytskyi-Shepetivka, 164-165 [in Ukrainian].

Savchuk, O. \& Savchuk, I. (1994). Volynske studentstvo 1920-30-kh rokiv - nova heneratsiia ukrainskoi natsionalnoi intelihentsii pershoi polovyny XX st. [Volyn' students of 1920-30's - a new generation of Ukrainian national intelligentsia of the first half of XX century]. Abstracts of Papers: «Volyn $i$ volynske zarubizhzhia» (Lutsk, 16-18 chervnia 1994 r.). Lutsk, 83-85 [in Ukrainian].

Sydorenko, N. (1999). Levytskyi Modest Petrovych [Levitsky Modest Petrovich]. In Ukrainska zhurnalistyka v imenakh. Materiali do entsiklopedichnogo slovnika, Vol. 6. Lviv [in Ukrainian].

Solovei, 0.H. (2004). Immigratsiini protsesy na Volyni u mizhvoiennyi period (1921-1939 rr.) [Immigration processes in Volyn in the interwar period (1921-1939)]. (Extended abstract of Candidate's thesis). Lviv [in Ukrainian].

Stepanov, L. \& Stepanova, L. (1991). Narodnyi oboronets [People's Defender]. Abstracts of Papers: V Volynska istoryko-kraieznavcha konferentsiia (11-13 zhovtnia 1991 roku) «Mynule i suchasne Volyni. Istorychni postati kraiu». Lutsk, 133-134 [in Ukrainian].

Tiutiunnyk, Yu. (1990). Z poliakamy proty Ukrainy [With the Poles against Ukraine]: Reprint (1924). Kyiv: Ukraina [in Ukrainian].

Tsetsyk, Ya.P. (2008). Diialnist ukrainskykh natsionalnykh partii na Volyni u mizhvoiennyi period [Activities of Ukrainian national parties in Volyn in the interwar period]. (Extended abstract of Candidate's thesis). Chernivtsi [in Ukrainian].

Zavadskaya, I., \& Kadenyuk, A. (2019). Political Factors in the Formation and Activity of Agricultural Societies in East Galicia (20s - early 30s XX century). Zaporizhzhia Historical Review, 1 (52), 150-154 [in English].

Zvarnyk, G. (1997). Zagadkovyi «vistkivets» Roman Bozheskyi. Lysty do Dmytra Dontsova [Mysterious «messenger» Roman Bozhesky. Letters to Dmitry Dontsov]. Ukrainski problemy, 2, 145-146 [in Ukrainian].

\section{Олександр Каденюк}

(Подільський державний університет, Кам'янець-Подільський, Україна)

e-mail: akadenyuk@gmail.com

ORCID: https://orcid.org/0000-0002-2173-6055

\section{Василь Сажко}

(Національний університет «Полтавська політехніка імені Юрія Кондратюка», Полтава, Україна)

e-mail: sazhkovv@gmail.com

ORCID: https://orcid.org/0000-0002-4372-3570

\section{Особливості діяльності суспільно-політичних і громадських організацій Волині у формуванні та розвитку ідеї української державності у 1921-1939 рр.}

У статті досліджуються історичні аспекти розвитку та становлення суспільнополітичних і громадських організацій Волині, яка після завершення Першої світової війни перебувала під владою двох тоталітарних держав - Радянського Союзу і Другої Речі Посполитої. Політика урядів цих держав привела до розгортання на Західній Волині національного руху. Основні політичні й інтелектуальні українські сили були зосереджені в імміграції на Волині та Галичині й у західноєвропейських країнах. Їх основу складав загартований у боях за УНР військовий елемент, вояки та старшини Української Армії. Саме на територіях захоплених Польщею почали утворюватися українські громадсько-культурні та політичні центри, які мали зв'язок з Радянською Україною та шукали оптимальні шляхи розв'язання національних проблем.

На 20-30 роки XX ст. припадає інтенсивний розвиток ідеології українського націоналізму. Поряд зі старою наддніпрянською інтелігенцією в імміграції зароджується нова генерація - молодь, яка орієнтувалася на ідею самостійності України. Ця боротьба захо- 
плювала широкі кола спочатку студентської та середньо-шкільної, а згодом і робітничої та селянської молоді.

Досліджено, що на території Волині, яка була у складі УРСР, український національний рух не мав змоги проявитися у властивих для нього організаційних формах і застосовувати таку ж саму тактику, що й на західноволинських землях. Але він реалізовувався, перш за все, у національно-культурному житті 20-х - початку 30-х рр. Це, у першу чергу, була діяльність Української Автокефальної Православної Церкви, яка своїми масовими виданнями та своєю організованістю впливала на значну частину українства 3 позицій національно-державної та церковної суверенності.

Ці факти дають підстави стверджувати, що ідеї національної незалежності були явищем всеукраїнським. На прикладі волинських земель прослідковано, що при всій різниці соціального та політичного ладу, який панував як на Західній, так і на Східній територіях Волині, незважаючи на різні обставини створені політичними режимами, процес формування національної ідеї являв собою органічну єдність на всіх українських землях.

Ключові слова: Україна, Волинь, національний рух, громадські організації, суспільно-політичні організації 